\title{
ANALISIS PERHITUNGAN DAN PELAPORAN PPH PASAL 21 PADA PT. SAMEROT TRI PUTRA
}

\author{
Ridelson Y.S. Warangkiran ${ }^{1}$, Jenny Morasa ${ }^{2}$, Lidia M. Mawikere $^{3}$ \\ 1,2,3 Jurusan Akuntansi, Fakultas Ekonomi dan Bisnis, Universitas Sam Ratulangi, Jl. Kampus Bahu, Manado, \\ 95115, Indonesia \\ E-mail : ridelyeremia@gmail.com
}

\begin{abstract}
Income tax Article 21 is tax on earnings in the form of wages, salaries, honorarium, benefits, and other payments by the name and in any form in connection with employment or Office, services, and activities performed by those Taxpayers persons in the country. On the basis that's then Government agencies or companies give salary to employees is obliged to apply the calculation and reporting of income tax Article 21 and received by employees correctly. This research was conducted on the company that is responsible for contracting i.e. PT. Samerot Tri Putra, the goal in this study was to analyze the calculation and reporting of income tax Article 21 carried out by PT. Samerot Tri Putra does were in accordance with Act No. 36 year 2008 about income tax. This research uses descriptive research methods with qualitative approaches. The results of this research show that the calculation and reporting of income tax Article 21 carried out by PT. Samerot Tri Putra has been in accordance with Act No. 36 year 2008 about income tax.
\end{abstract}

Keywords: Analysis, Reporting, Income Tax Article 21

\section{PENDAHULUAN}

Pajak Penghasilan Pasal 21 merupakan pajak penghasilan yang dipotong dari gaji maupun tunjangan dan penghasilan lainnya yang dikenakan kepada wajib pajak orang pribadi atau karyawan yang melakukan pekerjaan dalam negeri dan mendapatkan penghasilan dari pekerjaan yang dilakukannya. Maka dari itu, wajib pajak yang dalam hal ini orang pribadi atau karyawan yang memperoleh penghasilan maka akan dikenakan Pajak Penghasilan Pasal 21 yang akan disetor sendiri oleh wajib pajak ataupu perusahaan yang membeikan penghasilan kepada wajib pajak. PT. Samerot Tri Putra dalam memotong dan memungut PPh Pasal 21 yang terutang harus memiliki pengetahuan yang cukup tentang peraturan perundang-undangan yang berlaku. Dikarenakan terdapat perubahan regulasi dari pemerintah sehubungan dengan penetapan PTKP besar kemungkinan akan tersapat kesalahan pada saat penghitungan dan pelaporan PPh pada Perusahaan PT. Samerot Tri Putra.

PT. Samerot Tri Putra mempunyai jumlah karyawan yang banyak, ini membuat perusahaan ini mempunyai potensi yang cukup besar sehubungan dengan pembayaran pajak terutama dari Pajak Penghasilan Pasal 21 yang berimbas pada meningkatnya penerimaan negara. Selain dari pada itu, PT. Samerot Tri Putra sehubungan dengan PPh Pasal 21 juga bisa memilliki kemungkinan melakukan kesalahan dalam perhitungan PPh Pasal 21 ataupun dalam melakukan pelaporan $\mathrm{PPh}$ Pasal 21 yang mungkin diakibatkan dari perbedaan penentuan Penghasilan Tidak Kena Pajak ataupun unsur perpajakan lainnya. Ini juga menyebabkan akan terjadi kekeliruan terhadap pencatatan akuntansi juga kemungkinan mendapatkan sanksi perpajakan yang berlaku di Indonesia. 


\section{TINJAUAN PUSTAKA}

Akuntansi. Menurut Kartikahadi, dkk. (2016 : 3) mengungkapkan bahwa akuntansi bertujuan dalam pelaporan hasil informasi kepada pihak-pihak yang membutuhkan dalam bentuk laporan keuangan.

\section{Akuntansi Perpajakan}

Pengertian Akuntansi Perpajakan. Akuntansi pajak diterapkan untuk mencatat beberapa transaksi-transaksi yang memiliki keterkaitan dengan perpajakan. Maka dari itu, ini membuat wajib pajak dimudahkan dalam membuat Surat Pemberitahuan (SPT). Sedangkan Akuntansi komersial harus diterapkan sesuai dengan SAK dan peraturan perpajakan yang berlaku di dalam negeri. (Agoes 2014 : 10).

Konsep Dasar Akuntansi Perpajakan. Ada beberapa konsep dasar dalam Akuntansi Perpajakan menurut Agoes (2014 : 11) antara lain: (1) Pengukur Mata Uang; (2) Transaksi yang terjadi antara suatu usaha dengan pemiliknya harus terpisah; (3) Memiliki kesinambungan; (4) konsep historis; (5) Periode Akuntansi memiliki kesinambungan yang telah diatur dalam Pasal 28 ayat 6 Undang-Undang KUP nomor 16 tahun 2009; (6) Taat akan Asas; (7) Memiliki materialistis; (8) Penghasilan hanya akan diakui jiga terjadi transaksi, akan tetapi kerugian walaupun belum ada transaksi tetaapi dapat dicatat (konservatisme); (9) Apabila terjadinya suatu transaksi penjualan, penghasilan akan dilaporkan (realisasi); dan (10) Laba bersih ditentukan melalui perbedaan dari pemasukan dan pengeluaran.

\section{Pajak}

Pengertian Pajak. Prof. Dr. Rochmat Soemitro, SH dalam Mardiasmo (2016:1) mengungkapkan bahwa Pajak ialah pemberian uang dari masyarakat (iuran) untuk negara yang telah diatur dalam undang-undang yang bisa dilakukan paksaan dan tidak mendapatkan jasa timbal kontraprestasi secara langsung yang dipergunaka untuk pembayaran pada umumnya.

Fungsi Pajak. Ada dua fungsi dari pajak antara lain fungsi sumber budgeter dan fungsi regularend menurut Sari (2013 : 34) sebagai berikut: (1) Fungsi Sumber Keuangan Negara (budgeter); dan (2) Fungsi Pengatur (regularend)

Jenis Pajak. Menurut Resmi (2014 : 7) ada beberapa jenis-jenis dari pajak yaitu :

1. Berdasarkan Golongan: (a) Pajak Langsung; dan (b) Pajak Tidak Langsung.

2. Berdasaarkan sifat: (a) Pajak Subjektif; dan (b) Pajak Objektif.

3. Berdasarkan Lembaga Pemungut: (a) Pajak Negara; dan (b) Pajak Daerah

Tata Cara Pemungutan Pajak. Resmi (2014 : 9) dalam buku Perpajakan Teori dan Kasus, tata cara pemungutan pajak dikelompokkan menjadi 3, antara lain stelsel pajak, asas pemungutan pajak, dan sistem pemungutan pajak.

Pajak Penghasilan. Menurut Mardiasmo (2016 : 175) ada beberapa kategori wajib pajak $\mathrm{PPh}$ Pasal 21 antara lain:

1. Pejabat Negara

2. Aparatur Sipil Negara (ASN)

3. Karyawan yang melaksanakan pekerjaan dalam jabatan BUMN atau BUMD

4. Karyawan Tetap

5. Tenaga Kerja merupakan orang pribadi yang melakukan pekerjaan pada yang memberikan pekerjaan, dan hanya akan mendapatkan imbalan jika dia mellakukan pekerjaan.

6. Penerima Honorarium ialah orang pribadi yang mendapatkan dan menerima imbalan berhubungan dengan jasa, jabatan, atau kegiatan yang dilakukannya.

7. Penerima Upah merupakan orang pribadi yang memperoleh upah harian, upah mingguan, upah borongan, maupun upah satuan. 


\section{Status Wajib Pajak PPh Pasal 21}

1. Status Wajib Pajak antara lain :

a. Tidak Kawin

b. Kawin dan tanggungannya.

c. Kawin, istri memiliki pendapatan dan melakukani penggabungan dengan pendapatan uang diterima suami.

d. Hidup Berpisah, adalah status wajib pajak statusnya adalah hidup berpisah.

2. Tanggungan secara penuh merupakan anggota dari keluarga dan tidak mempunyai penghasilan kemudian keseluruhan biaya hidup yang diberikan oleh Wajib pajak..

Objek Pajak PPh Pasal 21. Menurut Resmi (2014 : 175) ada beberapa penghasilan yang dikenakan Pajak Penghasilan Pasal 21 antara lain :

1. Penghasilan yang didapat maupun didapatkan dengan terencana.

2. Penghasilan yang didapatkan ataupun diterima dengan tidak teratur.

3. Upah borongan, upah satuan, upah harian, dan upah mingguan.

4. Uang pesangon, Uang tebusan pensiun, uang jaminan hari tua, ataupun uang tabungan hari tua, lain sebagainya.

5. Hadiah, uang saku, honorarium, penghargaan, beasiswa, komisi, dan pembayaran lainnya yang mendapat imbalan karena pekerjaan dan jasa dari wajib pajak yang ada di dalam negeri.

Pemotong Pajak PPh Pasal 21. Pemotong pajak Dalam Peraturan Direktur Jenderal Pajak Nomor: PER-16/PJ/2016, yaitu: (1) Pemberi kerja yang terdiri dari; (2) Bendahara atau pemegang kas pemerintah; (3) Dana pensiun; (4) Orang pribadi; dan (5) Penyelenggara kegiatan.

\section{Tarif Pajak PPh Pasal 21}

Tabel 1. Tarif Pajak PPh Pasal 21

\begin{tabular}{lc}
\hline \multicolumn{1}{c}{ Penghasilan Kena Pajak } & Tarif Pajak \\
\hline Rp. 50.000.000,00 kebawah & $5 \%$ \\
Rp. 50.000.000,00 - Rp. 250.000.000,00 & $15 \%$ \\
250.000.000,00 - Rp.500.000.000,00 & $25 \%$ \\
Rp.500.000.000,00 keatas & $30 \%$ \\
\hline
\end{tabular}

Sumber: Pasal 17 ayat 1, UU Nomor 36 tahun 2008

\section{Penghasilan Tidak Kena Pajak}

Tabel 2. Penghasilan Tidak Kena Pajak

\begin{tabular}{cc}
\hline Status Wajib Pajak & PTKP Setahun \\
\hline TK & Rp54.000.000,00 \\
K/0 & Rp58.500.000,00 \\
K/2 & Rp63.000.000,00 \\
K/3 & Rp67.500.000,00 \\
\hline
\end{tabular}

Sumber: PMK Nomor. 101/PMK.010/2016

\section{Cara Menghitung Pajak Penghasilan Pasal 21}

Pegawai tetap A bekerja dengan status sudah menikah dan memiliki 3 anak, menerima penghasilan bruto dalam satu bulan sebesar Rp 7.000.000.

Gaji sebulan

Penghasilan bruto setahun
Rp. 7.000 .000

RP 84.000 .000 


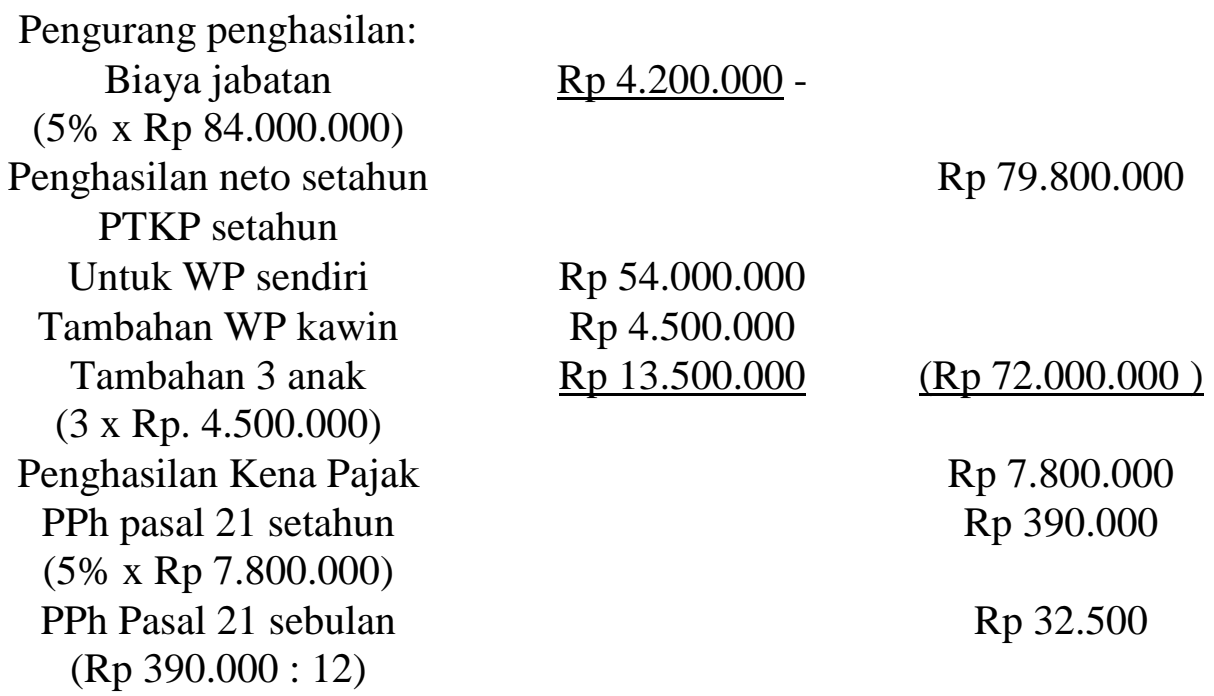

\section{Surat Pemberitahuan (SPT)}

Pengertian SPT. Suharsono (2014: 83) mendefinisikan SPT atau Surat Pemberitahuan merupakansurat yang dipergunakan oleh wajib pajak untuk melaporkan perhitunaganataupun membayar pajak adalah surat yang oleh Wajib Pajak digunakan untuk melaporkan penghitungan dan/atau pembayaran pajak, objek pajak dan/atau bukan objek pajak, dan/atau harta dan kewajiban sesuai dengan ketentuan peraturan perundang-undangan perpajakan.

Batas Waktu Penyampaian SPT. Lubis (2014: 19) menyatakan bahwa "PPh Pasal 21 dibayar paling lambat tanggal 10 bulan berikutnya menggunakan SSP (Surat Setoran Pajak), PPh Pasal 21 dilaporkan paling lambat tanggal 20 bulan berikutnya menggunakan SPT Masa PPh 21. Terlambat lapor PPh Pasal 21 dikenakan denda Rp100.000,00”.

Penelitian Terdahulu. Dalam penelitian ini ada beberapa penelitian terdahulu yang digunakan sebagai bahan pertimbangan sehubungan dengan penelitian. Penelitian yang dilakukan oleh Arham (2016) tentang Analisis perencanaan pajak untuk PPh pasal 21 pada PT. Pegadaian (PERSERO) cabang tuminting menjelaskan bahwa didapati kesalahan ketika perusahaan melakukan perhitungan PTKP yang mengakibatkan PPh 21 yang diitung menjadi lebih besar. Kemudian penelitian oleh Lumintang (2014) tentang Evaluasi perhitungan $\mathrm{PPh}$ Pasal 21 pegawai negeri sipil pada Dinas Sosial Provinsi Sulawesi Utara menjelaskan dalam pelaksanaan perhitungan Pajak Penghasilan Pasal 21 yang dilakukan telah sesuai dengan Undang-Undang Perpajakan tahun 2008.

\section{METODE PENELITIAN}

Jenis Penelitian. Pada penelitian ini peneliti memakai jenis penelitian deskriptif. Sugiyono (2015 : 22) mengungkapkan bahwa metode deskriptif merupakan suatu yang dipergunakan dalam memberikan gambaran ataupun menganalisa suatu hasil penelitian tapi tidak dipergunakan dalam menarik kessimpulan yang luas.

Tempat Dan Waktu Penelitian. Penelitian ini dilaksanakan pada PT. Samerot Tri Putra dengan waktu pelaksanaan penelitian dimulai sejak bulan Agustus 2018 sampai dengan selesai.

\section{Jenis Data Penelitian}

1. Menurut Kuncoro (2014 : 145) Data kualitatif pada penelitian ini adalah hasil wawancara, sejaraah, dan struktur organisasi PT. Samerot Tri Putra.

2. Menurut Kuncoro (2014 : 145) Data kuantitatif pada penelitian ini adalah: Gaji karyawan PT. Samerot Tri Putra, Perhitungan Pajak Penghasilan Pasal 21 PT. Samerot Tri Putra. Pelaporan Pajak Penghasilan Pasal 21 PT. Samerot Tri Putra. 
Sumber Data Penelitian. Sumber data penelitian yang diterapkan pada penelitian ini adalah data primer. Wawancara dan dokumentasi merupakan data primer dalam penelitian ini yang dilaksanakan di PT. Samerot Tri Putra.

\section{Metode Pengumpulan Data}

1. Wawancara. Wawancara ditanyakan kepada Kepala bagian Keuangan PT. Samerot Tri Putra.

2. Dokumentasi. Dokumentasi diterapkan melalui cara pengumpulan dokumen-dokumen untuk penelitian berhubungan dengan objek kajian yang akan diteliti pada PT. Samerot Tri Putra.

Metode dan Proses Analisis. Metode analisis deskriptif merupakan metode analisis yang akan digunakan dalam penelitian ini. Proses analisis yang akan digunakan:

1. Tahap pertama, mengumpulkan data dari PT. Samerot Tri Putra berupa Surat Setoran Pajak, SPT Masa PPh pasal 21, slip gaji karyawan, dan gambaran umum perusahaan.

2. Tahap kedua, menganalisa apakah perhitungan PPh pasal 21 pada PT. Samerot Tri Putra sudah sesuai dengan UU No 36 Tahun 2008.

3. Tahap ketiga, menganalisa apakah pelaporan PPh pasal 21 pada PT. Samerot Tri Putra sudah sesuai dengan UU No 36 Tahun 2008.

4. Tahap keempat, penulis menarik kesimpulan dari bahasan dan perbandingan yang telah dilakukan dalam tahap-tahap sebelumnya.

\section{HASIL PENELITIAN DAN PEMBAHASAN}

\subsection{Gambaran Umum PT. Samerot Tri Putra}

PT. Samerot Tri Putra adalah suatu perusahaan atau badan usaha milik swasta yang bergerak di bidang kontraktor bangunan dan kontraktor umum, proyek-proyek yang ditangani atau dikerjakan perusahaan ini antara lain adalah pembuatan jalan, pembuatan jembatan, pembuatan bangunan dan lain-lain. PT. Samerot Tri Putra secara resmi didirikan pada tanggal 22 januari 1982 dengan nama CV. Samerot Tri Putra yang berkedudukan di Tondano, Kabupaten Minahasa.

\subsection{Hasil Penelitian}

Pelaksanaan Perhitungan PPh Pasal 21 di PT. Samerot Tri Putra. PT. Samerot Tri Putra memiliki banyak karyawan dengan berbagai status yaitu karyawan tetap dan karyawan harian lepas yang bekerja atau bertugas di proyek dan bertugas di kantor. Dalam penelitian ini, peneliti telah mengumpulkan data-data yang berkaitan dengan Pajak Penghasilan Pasal 21 di PT. Samerot Tri Putra yang merupakan objek penelitian. Data-data Pajak Penghasilan yang telah dikumpulkan peneliti adalah data gaji karyawan, status karyawan, dan potongan atas Pajak Penghasilan Pasal 21. Dalam penelitian ini, peneliti hanya akan membatasi pada Pajak Penghasilan Pasal 21 atas karyawan tetap dan akan digunakan hanya 10 orang karyawan tetap di PT. Samerot Tri Putra sebagai sampel yang yang akan dibahas sehubungan dengan perhitungan Pajak Penghasilan Pasal 21. 
Tabel 3. Daftar gaji dan potongan PPh pasal 21 PT. Samerot Tri Putra

Bulan Agustus 2018

\begin{tabular}{cccccc}
\hline No & Nama & $\begin{array}{c}\text { Jenis } \\
\text { kelamin }\end{array}$ & Status & $\begin{array}{c}\text { Penghasilan } \\
\text { per bulan }\end{array}$ & PPh Pasal 21 \\
\hline 1 & A & L & K/1 & Rp 6.000.000 & Rp 22.500 \\
2 & B & L & TK & Rp 5.150.000 & Rp19.625 \\
3 & C & L & TK & Rp 5.000.000 & Rp 12.500 \\
4 & D & L & TK & Rp 5.000.000 & Rp 12.500 \\
5 & E & L & TK & Rp 5.150.000 & Rp19.625 \\
6 & F & L & K/2 & Rp 5.000.000 & Nihil \\
7 & G & L & K/1 & Rp 4.500.000 & Nihil \\
8 & H & P & TK & Rp 4.000.000 & Nihil \\
9 & I & L & K/2 & Rp 5.150.000 & Nihil \\
10 & J & P & TK & Rp 4.000.000 & Nihil \\
\hline
\end{tabular}

Sumber: PT. Samerot Tri Putra

\section{Pelaksanaan Pelaporan PPh Pasal 21 di PT. Samerot Tri Putra}

Berikut ini merupakan mekanisme pelaporan PPh pasal 21 yang dilakukan di PT. Samerot Tri Putra adalah sebagai berikut :

Nama Wajib Pajak

Alamat

NPWP

: PT. Samerot Tri Putra

:Kelurahan Sendangan, Kecamatan Kawangkoan, Kabupaten Minahasa.

: 02.700.975.2.823000

1. Bagian administrasi dan keuangan melakukan pengisian SPT Masa PPh Pasal 21 dengan lengkap dan jelas.

2. Melaporkan SPT secara online menggunakan e-flling.

3. Memperoleh tanda terima penyampaian SPT.

\subsection{Pembahasan}

Perhitungan PPh Pasal 21. Berdasarkan tabel 4.1 yaitu daftar gaji karyawan dan perhitungan Pajak Penghasilan Pasal 21 di PT. Samerot Tri Putra, maka berikut ini peneliti akan menjabarkan hasil analisa yang dilakukan peneliti yaitu mengenai perhitungan Pajak Penghasilan Pasal 21 PT. Samerot Tri Putra yang mengacu pada UU No. 36 Tahun 2008 tentang Pajak Penghasilan sebagai berikut:

Pegawai A menikah dan memiliki tanggungan 1 orang anak bekerja di PT. Samerot Tri Putra dengan memperoleh gaji perbulan sebesar Rp. 6.000.000. maka perhitungan PPh Pasal 21 adalah sebagai berikut:

Gaji sebulan

Penghasilan bruto setahun

Pengurang penghasilan:

Biaya jabatan

(5\% x Rp 72.000.000)

Penghasilan neto setahun

PTKP setahun

Untuk WP sendiri

Tambahan WP kawin

Tambahan 1 anak

(1 x Rp. 4.500.000)

Penghasilan Kena Pajak

PPh pasal 21 setahun

(5\% x Rp 5.400.000)
Rp. 6.000 .000

RP 72.000.000

$\underline{\operatorname{Rp} 3.600 .000}$ -

Rp 68.400.000

Rp 54.000.000

Rp 4.500.000

$\underline{\operatorname{Rp} 4.500 .000}$

$\underline{(\mathrm{Rp} 63.000 .000)}$

Rp 5.400.000

Rp 270.000 
PPh Pasal 21 sebulan

$\operatorname{Rp} 22.500$

$(\operatorname{Rp} 270.000: 12)$

Dari hasil analisis diatas, maka peneliti akan membandingkan perhitungan $\mathrm{PPh}$ Pasal 21 yang dilaksanakan oleh perusahaan dibandingkan dengan hasil perhitungan yang dilaksanakan oleh peneliti berdasarkan aturan perundang-undangan yaitu UU nomor 36 tahun 2008 dibawah ini:

Tabel 4. Perbandingan perhitungan PPh Pasal 21

\begin{tabular}{|c|c|c|c|c|c|}
\hline \multirow[t]{2}{*}{ No } & \multirow[b]{2}{*}{ Nama } & \multicolumn{2}{|c|}{ PPh Pasal 21} & \multicolumn{2}{|l|}{ Menurut } \\
\hline & & Per bulan & Per tahun & $\begin{array}{l}\text { Undang- } \\
\text { Undang }\end{array}$ & Selisih \\
\hline 1 & A & $\operatorname{Rp} 22.500$ & $\operatorname{Rp} 270.000$ & $\operatorname{Rp} 22.500$ & - \\
\hline 2 & B & Rp19.800 & $\operatorname{Rp} 238.000$ & Rp19.625 & - \\
\hline 3 & $\mathrm{C}$ & Rp 12.500 & $\operatorname{Rp} 150.000$ & Rp 12.500 & - \\
\hline 4 & $\mathrm{D}$ & $\operatorname{Rp} 12.500$ & $\mathrm{Rp} 150.000$ & Rp 12.500 & - \\
\hline 5 & $\mathrm{E}$ & Rp19.625 & $\mathrm{Rp} 235.500$ & Rp19.625 & - \\
\hline 6 & $\mathrm{~F}$ & Nihil & Nihil & Nihil & - \\
\hline 7 & G & Nihil & Nihil & Nihil & - \\
\hline 8 & $\mathrm{H}$ & Nihil & Nihil & Nihil & - \\
\hline 9 & I & Nihil & Nihil & Nihil & - \\
\hline 10 & $\mathrm{~J}$ & Nihil & Nihil & Nihil & - \\
\hline
\end{tabular}

Sumber: Data diolah 2018

Berdasarkan dari hasil perhitungan diatas yang dilakukan oleh penullis tentang Pajak Penghasilan Pasal 21 pada PT. Samerot Tri Putra, berdasarkan data yang telah diolah peneliti didapati bahwa dalam perhitungan PPhPasal 21 yang dilaksanakan oleh PT. Samerot Tri Putra sudah dilakukan dengan baik dan benar sesuai dengan peraturan perundang-undangan berdasarkan UU Nomor 36 tahun 2008 tentang pemotongan pajak atas penghasilan yang didapat atau diterima Wajib Pajak dalam hal ini karyawan sehubungan dengan pekerjaan karena tidak didapatinya selisih kurang bayar atau lebih bayar PPh Pasal 21 yang terutang antara penghitungan yang dilaksanakan oleh perusahaan dan penghitungan yang dilaksanakanoleh peneliti.

Pelaporan PPh Pasal 21. Berdasarkan dari hasil analisa data dalam penelitian ini, PT. Samerot Tri Putra dalam melaksanakan pelaporan Pajak Penghasilan Pasal 21 sudah dilakukan dengan baik dan benar sesuai dengan peraturan perundang-undangan berdasarkan Undang-Undang Nomor 36 tahun 2008 tentang pajak penghasilan yaitu sebelum tanggal 20 pada bulan berikutnya atau setelah masa pajak. Pelaporan SPT Masa PPh Pasal 21 yang dilaksanakan PT. Samerot Tri Putra dilakukan di Kantor Pelayanan Pajak (KPP) Pratama Bitung tapi sejak April 2018, perusahaan melaporkan SPT masa PPh Pasal 21 secara online menggunakan e-filing karena dalam Peraturan Menteri Keuangan (PMK) Nomor 9 /PMK.03/2018 menyatakan bahwa perusahaan wajib melaporkan SPT Masa PPh Pasal 21 secara online. Beberapa karyawan yang bekerja di PT. Samerot Tri Putra ada yang bebas pajak atau tidak dikenakan pajak karena penghasilan yang didapat lebih kecil dari Penghasilan Tidak Kena Pajak (PTKP) ini berarti PPh Pasal 21 dari karyawan tersebut adalah nihil, oleh karena itu maka perusahaan tidak melaporkan SPT masa nihil karyawan yang penghasilannya di bawah PTKP. Hal ini telah sesuai dengan Peraturan Menteri Keuangan (PMK) Nomor 9 /PMK.03/2018 yang menyebutkan bahwa wajib pajak dibebakan dari kewajiban pelaporan SPT Masa Nihil. 


\section{KESIMPULAN DAN SARAN}

\subsection{Kesimpulan}

Berdasarkan dari hasil penelitian dan pembahasan pada bab sebelumnya, maka dapat diambil kesimpulan bahwa:

1) Perhitungan PPh Pasal 21 yang telah dilakukan oleh PT. Samerot Tri Putra sudah sesuai dengan aturan berdasarkan undang-undang yang berlaku di Negara Indonesia sebagaimana yang di maksud dalam Undang-Undang perpajakan yaitu UndangUndang Nomor 36 Tahun 2008 tentang Pajak Penghasilan. Karyawan yang penghasilannya dibawah Penghasilan Tidak Kena Pajak (PTKP) di PT. Samerot Tri Putra tidak dilakukan pemotongan Pajak Penghasilan Pasal 21 atas gaji karyawan sehingga Pajak Penghasilan Pasal 21 yang terutang adalah Nihil.

2) Pelaporan SPT masa PPh Pasal 21 yang diterapkan oleh PT. Samerot Tri Putra ke Kantor Pelayanan Pajak (KPP) telah dilaksanakan secara tepat waktu yaitu selambatlambatnya 20 hari setelah akhir masa pajak itu artinya pelaporan Pajak Penghasilan Pasal 21 di PT. Samerot Tri Putra telah sesuai dengaan aturan perpajakan yang berlaku sebagaimana yang dimaksud dalam Undang-Undang Nomor 36 tahun 2008 tentang Pasak Penghasilan.

\subsection{Saran}

Berdasarkan kesimpulan di atas, maka adapun saran yang diajukan kepada PT. Samerot Tri Putra adalah:

1) Karyawan PT. Samerot Tri Putra yang menangani perpajakan diharapkan untuk mengikuti setiap perkembangan peraturan dan ketentuan perpajakan terbaru yang selalu mengalami pembaharuan, sehingga di kemudian hari tidak akan terjadi kesalahan dalam penetapan pajak yang terutang khususnya dalam penetapan Pajak Penghasilan Pasal 21 selaras dengan aturan dalam perpajakan yakni UU Nomor 36 tahun 2008dan PMK.

2) PT. Samerot Tri Putra diharapkan untuk tetap selalu melaksanakan perhitungan Pajak Penghasilan Pasal 21 dengan baik dan benar sesuai dengan peraturan perundangundangan sehingga ketika melakukan penyetoran dan pelaporan PPh Pasal 21 tidak akan terjadi kesalahan yang dapat merugikan perusahaan.

\section{DAFTAR PUSTAKA}

Agoes, Sukrisno. 2014. Auditing Petunjuk Praktis Pemeriksaan Akuntan oleh Akuntan Publik. Edisi ke 4. Buku 1. Salemba Empat. Jakarta.

Arham, M.I. 2016. Analisis Perencanaan Pajak Intuk PPh Pasal 21 pada PT. Pegadaian (PERSERO) Cabang Tuminting. Skripsi. Universitas Sam Ratulangi. Manado.

Kartikahadi, H. 2016. Akuntansi keuangan berdasarkan SAK berbasis IFRS. Buku 1. Salemba Empat. Jakarta

Kuncoro, M. 2014. Metode Riset untuk Bisnis \& Ekonomi. Edisi Keempat. Erlangga. Yogyakarta.

Lubis, A. 2014. Mahir akuntansi pajak terapan berbasis standar akuntansi dan ketentuan pajak terbaru. Andi. Yogyakarta.

Lumintang, Tinangon, Elim. 2014. Evaluasi perhitungan PPh Pasal 21 pegawai negeri sipil pada Dinas Sosial Provinsi Sulawesi Utara. Skripsi. Universitas Sam Ratulangi. Manado.

Mardiasmo. 2016. Perpajakan. CV Andi Offset. Yogyakarta.

Resmi, S. 2014. Perpajakan teori dan kasus. Salemba Empat. Jakarta.

Sari, D. 2013. Konsep Dasar Akuntansi Perpajakan. Refika Aditama. Bandung.

Suharsono, A. 2014. Ketentuan umum perpajakan. Graha ilmu. Yogyakarta. 
Sugiyono. 2015. Metode Penelitian Kuantitatif Kualitatif $R \& B$. Alfabeta. Bandung

Undang-Undang Nomor 17 Tahun 2000 tentang Pajak Penghasilan. Perubahan Ketiga atas Undang-undang Nomor 7 Tahun 1983.

Undang-Undang Nomor 36 Tahun 2008 tentang Pajak Penghasilan. Perubahan Keempat atas Undang-undang Nomor 7 Tahun 1983

Weygandt, Kimmel and Kieso. 2013. Financial Accounting: IFRS Edition. Hoboken. John Wiley and Sons, Inc. 